\title{
IDENTIFIKASI PEMANFAATAN AIR BERSIH DI PERMUKIMAN PERKOTAAN (STUDI KASUS KELURAHAN SUNGAI BANGKONG KOTA PONTIANAK)
}

\author{
Emilya Kalsum \\ Program Studi Arsitektur Universitas \\ Tanjungpura Pontianak \\ emilyakalsum@teknik.untan.ac.id
}

\author{
Tri Wibowo Caesariadi \\ Program Studi Arsitektur Universitas \\ Tanjungpura Pontianak \\ tricaesariadi@teknik.untan.ac.id
}

\author{
Yudi Purnomo \\ Program Studi Arsitektur Universitas \\ Tanjungpura Pontianak \\ yudipurnomo@teknik.untan.ac.id
}

\begin{abstract}
Abstrak
Hujan merupakan salah satu sumber air bersih yang sangat potensial di wilayah tropis basah. Kelurahan Sungai Bangkong Kota Pontianak merupakan wilayah yang memiliki curah hujan dalam kategori menengah-tinggi. Di wilayah ini, hujan memiliki potensi sebagai sumber air bersih dan juga sekaligus sebagai penyebab genangan. Wilayah ini juga merupakan kawasan permukiman dengan kepadatan yang tinggi yang membutuhkan cukup besar suplai air. Penelitian ini mencoba memberikan gambaran tentang pemanfaatan air bersih di wilayah permukiman perkotaan.

Penelitian ini menggunakan pendekatan statistika deskriptif. Beberapa variabel yang akan dijelaskan adalah sumber air, penampungan air, sistem aliran, tinggi, durasi dan penyebab genangan. Penelitian memberikan gambaran tentang perlunya peningkatan penampungan dan pemanfaatan air hujan untuk memenuhi kebutuhan air bersih di kawasan permukiman. Hasil yang diperoleh dalam penelitian ini adalah air hujan tetap menjadi sumber air bersih warga, namun pemanfaatannya relatif lebih rendah dibandingkan penggunaan air yang berasal dari PDAM dan air tanah.
\end{abstract}

Kata-kata Kunci: Air hujan, permukiman, perkotaan, Kota Pontianak

\section{IDENTIFICATION OF USE OF CLEAN WATER IN URBAN SETTLEMENT AREA (A CASE STUDY OF KELURAHAN SUNGAI BANGKONG KOTA PONTIANAK)}

\begin{abstract}
Rain is one of the potential clean water sources in the wet tropics area. Kelurahan Sungai Bangkong, Kota Pontianak, is an area that has rainfall in the middle-high category. In this region, rain has the potential as a source of clean water and also as a cause of runoff. It is also a high density settlement area that requires a substantial supply of water. This research tries to describe the utilization of clean water in urban settlement area.

This research uses descriptive statistical approach. Some of the variables to be explained are water source, water reservoir, flow system, height, duration and cause of runoff. The study provides an overview of the need to increase rainwater storage and utilization to meet clean water needs in residential areas. The results obtained in this study is that rainwater remains the main source of
\end{abstract}


clean water for residents, but its utilization is relatively lower than the use of water coming from PDAM and other sources.

Keywords: precipitation, rainwater, urban settlement, Kota Pontianak

\section{Pendahuluan}

Kawasan permukiman merupakan kawasan yang mendominasi pemanfaatan ruang di wilayah perkotaan. Kawasan terbangun non pertanian menjadi dominasi permukiman di perkotaan. Kota Pontianak mengalami peningkatan wilayah terbangun non pertanian, khususnya untuk fungsi permukiman. Pemanfaatan lahan non pertanian berada di atas $80 \%$ untuk wilayah di Kecamatan Pontianak Barat dan Kecamatan Pontianak Kota (Purnomo \& Wulandari, 2015). Peningkatan perubahan pemanfaatan lahan juga terjadi di wilayah kecamatan lainnya di Kota Pontianak.

Kota Pontianak merupakan ibukota Provinsi Kalimantan Barat sekaligus menjadi pusat perekonomian. Pembangunan dengan intensitas yang tinggi telah menjadikan Kota Pontianak memiliki tingkat kepadatan yang tinggi dibandingkan dengan daerah lainnya. Kepadatan perkotaan yang tinggi menuntut pemenuhan kebutuhan dasar yang relatif juga besar dan terkonsentrasi di kawasan permukiman. Salah satu kebutuhan dasar yang cukup besar dibutuhkan oleh warga adalah air bersih.

Pemenuhan kebutuhan air bersih di Kota Pontianak selain disediakan oleh alam melalui air hujan, air sungai, dan air tanah, juga di penuhi oleh Perusahaan Daerah Air Minum (PDAM). Saat ini pelayanan PDAM baru menjangkau 63,54\% rumah tangga yang ada di Kota Pontianak (Purnomo \& Wulandari, 2017). Sementara debit air yang dialirkan oleh PDAM masih tergantung kepada kondisi air sungai yang menjadi sumber air olahan. Kondisi ini menjadikan beberapa wilayah di Kota Pontianak belum mendapatkan aliran air yang mencukupi kebutuhan.

Sulitnya aliran air yang dialami warga di Kota Pontianak saat ini sebenarnya berbanding terbalik dengan potensi air bersih yang berasal dari curah hujan. Sebagai kota yang terletak di wilayah khatulistiwa, secara geografis terletak di $0^{\circ} 02$ '24" Lintang Utara sampai dengan $0^{\circ} 05^{\prime} 37^{\prime \prime}$ Lintang Selatan, dan $109^{\circ} 16^{\prime} 25^{\prime \prime}$ Bujur Timur sampai dengan $109^{\circ} 23^{\prime} 01^{\prime \prime}$ Bujur Timur, menjadikan wilayah ini memiliki curah hujan rata-rata bulanan dalam kategori menengah-tinggi serta konstan, yaitu 282,43 mm dan 23 hari (BPS Kota Pontianak, 2017). Data ini mengindikasikan besarnya potensi air hujan yang dapat menjadi sumber air bersih warga di Kota Pontianak.

Besarnya potensi air bersih yang berasal dari air hujan saat ini ternyata juga menjadi ancaman bagi warga Kota Pontianak. Selain karena faktor kondisi geografis, berada di antara 0,10 s.d. 1,50 meter di atas permukaan laut, faktor curah hujan yang cukup besar menjadikan hampir sebagian besar wilayah Kota Pontianak memiliki potensi genangan. Salah satu persoalan terkait potensi genangan adalah air hujan dan koefisien aliran permukaan (runoff). Kedua pokok persoalan ini akan dipengaruhi oleh beberapa faktor lain seperti lokasi, bentang alam, infiltrasi, kondisi permukaan, dan berbagai variabel lainnya. Faktor yang terlihat secara alamiah adalah infiltrasi dan curah hujan. Sedangkan faktor buatan manusia adalah kondisi permukaan berupa pola ruang dan intensitas pemanfaatan ruang (Purnomo \& Wulandari, 2017). 


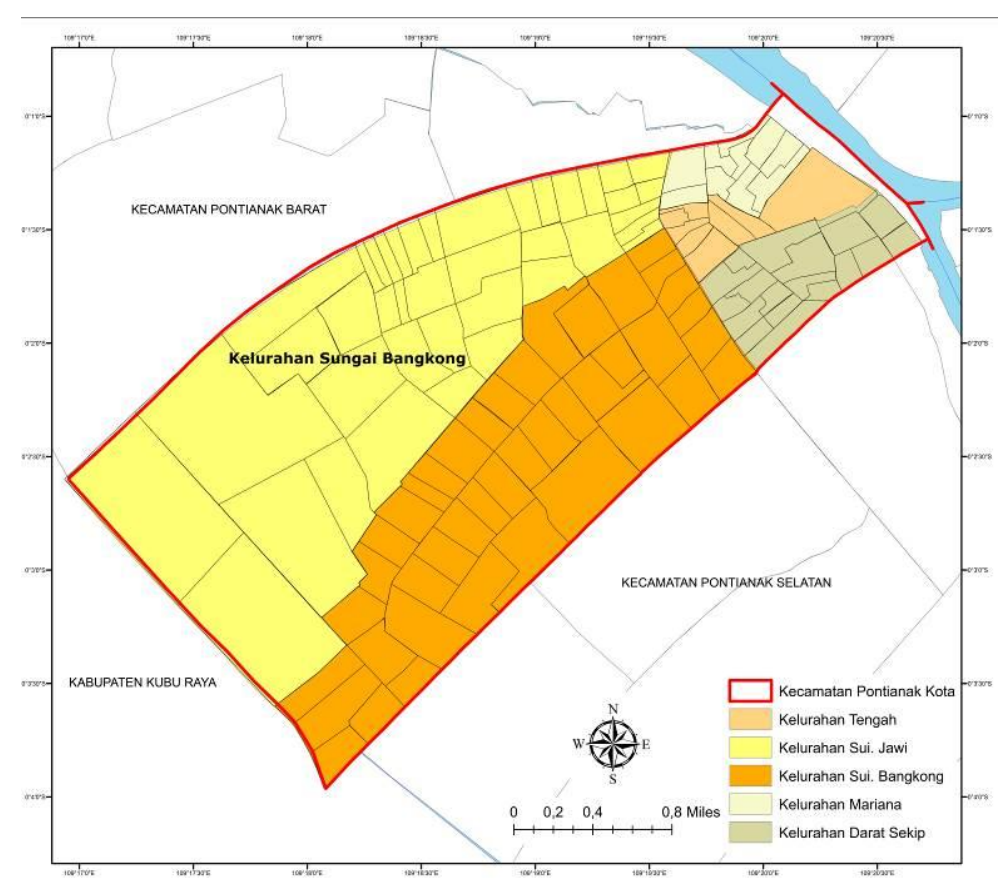

Gambar 1. Peta Administrasi Kecamatan Pontianak Kota Sumber: Purnomo, Kalsum, \& Caesariadi, 2017

Kelurahan Sungai Bangkong adalah salah satu kelurahan yang terdapat di Kecamatan Pontianak Kota yang mengalami genangan yang cukup parah di beberapa bagian wilayahnya. Sementara itu wilayah ini cenderung terletak cukup jauh dari wilayah yang memiliki potensi genangan akibat pasang surut air sungai. Dominasi peruntukan wilayah yang sebagian besar merupakan permukiman warga menjadi wilayah ini menarik untuk diteliti mengenai potensi pemanfaatan air bersih terhadap potensi genangan yang terjadi wilayah ini.

Penelitian ini dimaksudkan untuk memberikan gambaran mengenai pemanfaatan sumber air bersih oleh warga, khususnya yang berasal dari air hujan. Selain itu, tulisan ini juga memberikan gambaran genangan dan perubahan genangan yang terjadi wilayah studi (Kelurahan Sungai Bangkong) menurut preferensi warga. Hal ini perlu diketahui untuk menjadi bahan penelitian lebih lanjut mengenai perencanaan pengendalian air hujan dan pemanfaatannya di kawasan permukiman.

\section{Kajian Pustaka}

\section{Kebutuhan air}

Kebutuhan air dalam bangunan adalah air yang dipergunakan baik oleh penghuni bangunan ataupun untuk keperluan-keperluan lain yang ada kaitannya dengan fasilitas bangunan. Kebutuhan air didasarkan kepada (Tangoro, 2006):

- Keperluan-keperluan: (i) untuk minum, memasak/dimasak; (ii) untuk keperluan mandi, buang air kecil dan air besar; (iii) untuk mencuci, cuci pakaian, cuci tangan/badan, cuci peralatan dan cuci perlengkapan; serta (iv) untuk proses seperti industri.

- Kebutuhan yang sifatnya sirkulasi: (i) air panas; (ii) water cooling/AC; dan (iii) kolam renang, air mancur/taman

- Kebutuhan yang sifatnya tetap: (i) air untuk hydrant ; dan (ii) air untuk sprinkler

- Kebutuhan air cadangan yang sifatnya berkurang karena penguapan.

Besar kebutuhan air, khususnya untuk kebutuhan manusia, dihitung rata-rata per orang per hari tergantung dari jenis bangunan yang digunakan untuk kegiatan manusia tersebut. Gambar 2 menjelaskan proporsi pemakaian air menurut penggunaannya bagi manusia. Mandi, peturasan, dan 
penggelontoran kloset merupakan konsumsi terbesar dalam penggunaan air. Sedangkan minum dan memasak hanya $4 \%$ dari seluruh penggunaan air harian manusia.

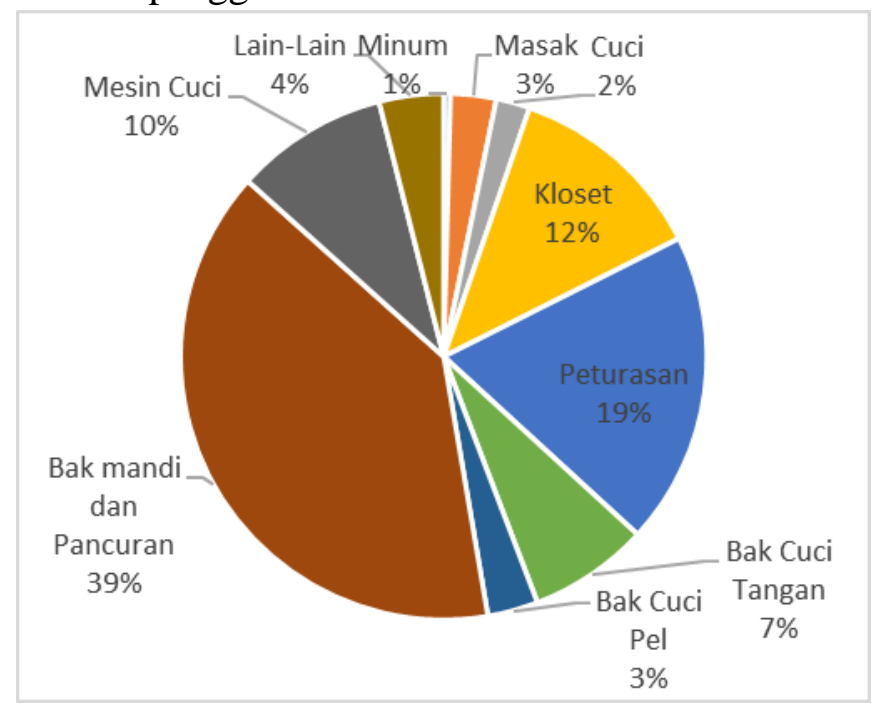

Gambar 2. Pemakaian Air Menurut Penggunaannya

Sumber: Noerbambang \& Morimura, 2000

\section{Penyimpanan Air Bersih}

Dalam proses distribusi air bersih harus disimpan dalam beberapa tahap tergantung pada penggunaannya diperlukan tempat penyimpanan dengan berbagai kapasitas. Air dapat disimpan (Lippsmeier, 1997):

- Di dalam tanah sebagai reservoir alamiah

- Di dalam bak penampung sebelum diolah

- Di dalam bak penampung setempat ( tangki atau menara air)

- Di dalam bak penampung pada proses suatu bangunan

Angka pendekatan untuk luas yang diperlukan untuk menyimpan air didapatkan dari perkiraan konsumsi per orang setiap hari dikalikan dengan jumlah penduduk dan lama penyimpanan yang diperlukan biasanya angka pendekatan untuk luas yang diperlukan untuk penyimpanan air didapatkan dari perkiraan konsumsi per orang setiap hari dikalikan dengan jumlah penduduk dan lama penyimpanan yang diperlukan (biasanya minimal 2 hari). Luas yang dicari adalah dari volume yang diperlukan dibagi dengan tinggi bak penampung.

\section{Pengelolaan Air Hujan}

Peraturan Menteri Pekerjaan Umum Republik Indonesia Nomor 11/PRT/M/2014 tentang Pengelolaan Air Hujan Pada Bangunan Gedung dan Persilnya disebutkan bahwa pertimbangan pengelolaan dan pemanfaatan air hujan perlu dilakukan untuk mempertahankan siklus air dan kondisi hidrologi alami, serta pemenuhan kebutuhan air pada bangunan gedung. Pertimbangan pemanfaatan air hujan antara lain adalah (Peraturan Menteri Negara Lingkungan Hidup Nomor 12 Tahun 2009 tentang Pemanfaatan Air Hujan):

1) Air hujan merupakan sumber air yang dapat dimanfaatkan sebagai imbuhan air tanah dan atau dimanfaatkan secara langsung untuk mengatasi kekurangan air pada musim kemarau dan banjir pada musim hujan.

2) Semakin meningkatnya kegiatan pembangunan mengakibatkan berkurangnya daerah resapan air yang dapat menimbulkan kerusakan lingkungan 
Pemilihan jenis sarana pengelolaan air hujan mempertimbangkan persyaratan, kebutuhan pemilik atau pengguna bangunan gedung, serta skala prioritas pola pengelolaan air hujan, antara lain (Permen PU No.11/2014):

1) Memaksimalkan pemanfaatan air hujan pada bangunan gedung dan persilnya

2) Memaksimalkan infiltrasi air hujan, dan

3) Menahan air hujan sementara waktu untuk menurunkan limpasan air hujan

\section{Metode Penelitian}

Penelitian ini memilih lokasi di Kelurahan Sungai Bangkong Kecamatan Pontianak Kota. Kelurahan ini dijadikan kasus penelitian dikarenakan beberapa pertimbangan antara lain:

- Kelurahan Sungai Bangkong ini berada relatif cukup jauh dari Sungai Kapuas, sehingga dapat meminimalisasi pengaruh pasang surut air sungai pada lokasi.

- Lokasi ini mewakili jenis tanah yang ada di Kota Pontianak. Sebagian wilayah dari Kelurahan Sungai Bangkong dan Kelurahan Akcaya memiliki lahan yang tertutup oleh lapisan tanah gambut.

- Kelurahan Sungai Bangkong memiliki tingkat kepadatan yang relatif serupa dan didominasi oleh peruntukan lahan permukiman.

- Wilayah kelurahan telah terlayani secara merata oleh jaringan PDAM.

Sebuah sampel adalah bagian dari populasi. Survei sampel adalah suatu prosedur di mana hanya sebagian dari populasi saja yang diambil dan dipergunakan untuk menentukan sifat serta ciri yang dikehendaki dari populasi. Penentuan sampel dalam penelitian ini menggunakan probability sample. Probability sample adalah sampel yang ditarik sedemikian rupa, di mana suatu elemen (unsur) individu dari populasi tidak didasarkan pada pertimbangan pribadi, tetapi tergantung kepada aplikasi kemungkinan (Nazir, 2003).

Pengambilan sampel dalam penelitian ini dilakukan dengan menggunakan Metode Slovin. Metode ini merupakan salah satu metode praktis dalam menentukan jumlah sampel (Sujarweni, 2015). Metode ini menentukan ukuran sampel minimal (n) jika diketahui ukuran populasi (N) pada taraf signifikansi $\alpha$ adalah:

Jumlah sampel yang diambil dari data jumlah penduduk di Kelurahan Sungai Bangkong dan Kelurahan Akcaya dengan taraf signifikansi $(\alpha)$ sebesar 7\%, diperoleh hasil sebagai berikut:

Tabel 1. Jumlah KK dan Jumlah Sampel

\begin{tabular}{ccrc}
\hline No & Nama Kelurahan & Jumlah KK & \multicolumn{2}{c}{ Jumlah Sampel } \\
$(\boldsymbol{\alpha}=\mathbf{7 \%})$
\end{tabular}

Sumber: Analisis, 2017

Statistika deskriptif adalah metode-metode yang berkaitan dengan pengumpulan dan penyajian suatu gugus data sehingga memberikan informasi yang berguna. Jadi, perlu kiranya dipahami bahwa statistika deskriptif memberikan informasi hanya mengenai data yang dipunyai dan sama sekali tidak menarik inferensia dan kesimpulan apa pun tentang gugus data induknya yang lebih besar. Statistika deskriptif adalah statistika yang berfungsi untuk mendeskripsikan atau memberi gambaran terhadap obyek yang diteliti melalui data sampel atau populasi sebagaimana adanya, tanpa melakukan analisis dan membuat kesimpulan yang berlaku untuk umum. (Santoso, 2015)

Analisis deskriptif dalam penelitian ini digunakan untuk memberikan gambaran terhadap data sekunder dan data primer yang diperoleh. Adapun beberapa data yang disajikan menggunakan analisis deskriptif adalah gambaran umum lokasi penelitian, data responden, dan beberapa data terkait variabel lahan dan bangunan, sistem aliran air hujan, penampungan air, jenis pemakaian air, penggunaan air bersih, kondisi drainase, genangan dan perubahan akibat genangan yang terjadi. 


\section{Hasil dan Pembahasan}

Sesuai dengan jumlah sampel yang direncanakan, terkumpul 149 sampel berasal dari Kelurahan Sungai Bangkong. Data dari sampel yang diperoleh dikelompokkan menjadi karakteristik responden, bangunan dan lahan, aliran dan penampungan air hujan, penggunaan air bersih, serta kondisi drainase dan genangan.

\section{Karakteristik Responden}

\section{A. Lama Tinggal}

Lama tinggal responden di Kelurahan Sungai Bangkong cukup bervariasi. Tercatat rata-rata lama tinggal adalah 26 tahun, dengan jumlah responden paling banyak tinggal selama 10 tahun yaitu sebesar $7,4 \%$. Sementara itu tercatat pula bahwa ada responden yang sudah tinggal selama 90 tahun di Kelurahan Sungai Bangkong.

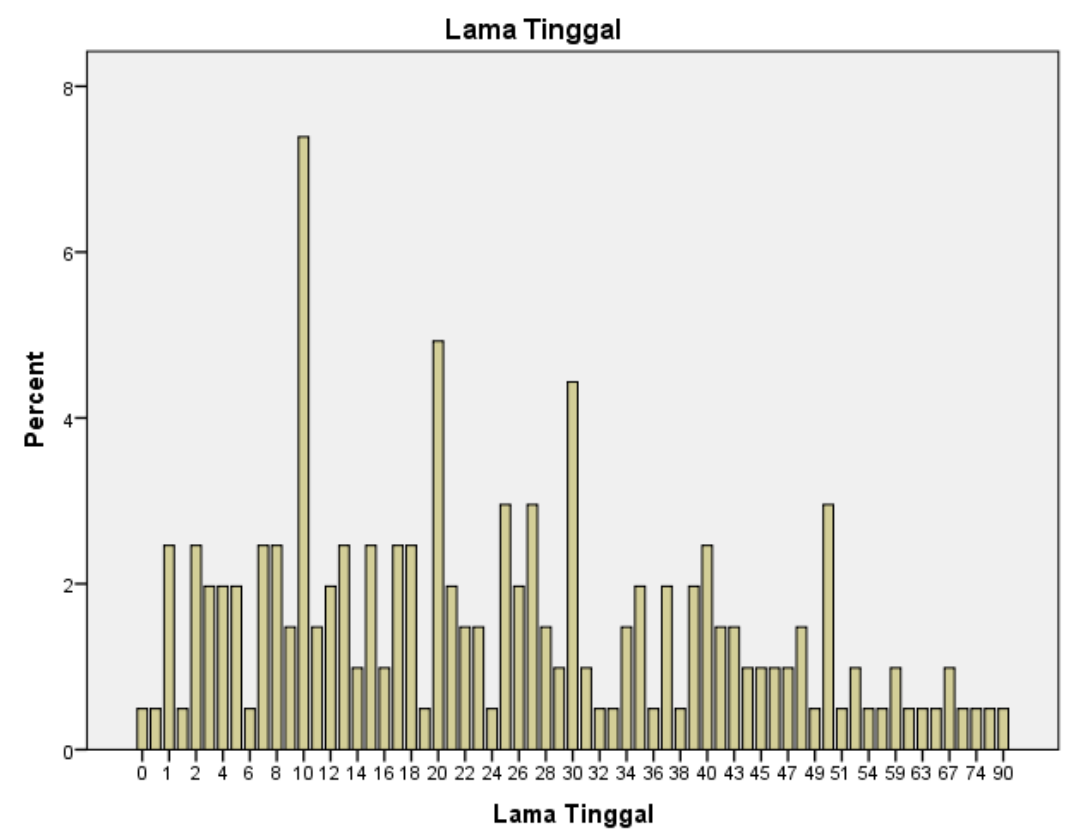

Gambar 3. Lama Tinggal

\section{B. Jumlah Penghuni}

Sumber: Analisis, 2017

Rata-rata jumlah penghuni dalam satu keluarga di Kelurahan Sungai Bangkong adalah 5 orang per rumah. Penghuni dengan frekuensi paling banyak adalah 4 orang per rumah. Jumlah penghuni terbesar adalah 20 orang sedangkan jumlah penghuni paling kecil adalah rumah yang hanya ditinggali satu orang saja. 


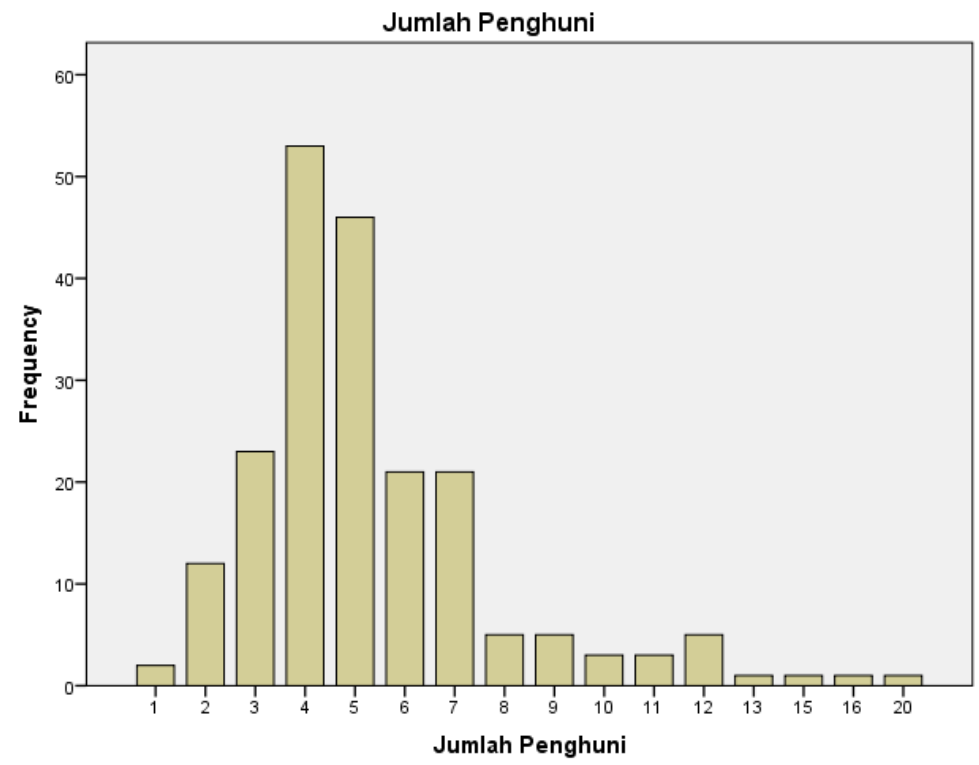

Gambar 4. Jumlah Penghuni

Sumber: Analisis, 2017

\section{Status Rumah}

Sebagian besar rumah di Kelurahan Sungai Bangkong merupakan milik sendiri yaitu sebesar $81 \%$. Sebanyak $8 \%$ rumah merupakan sewa/kontrak dan $10 \%$ sampel menumpang. Ada 2 sampel yang rumahnya berstatus rumah dinas. Beberapa sampel yang beranggapan status rumah sewa maupun dinas membuatnya tidak ingin merekonstruksi rumah, sekalipun lingkungan semakin parah tiap tahunnya akibat banjir.

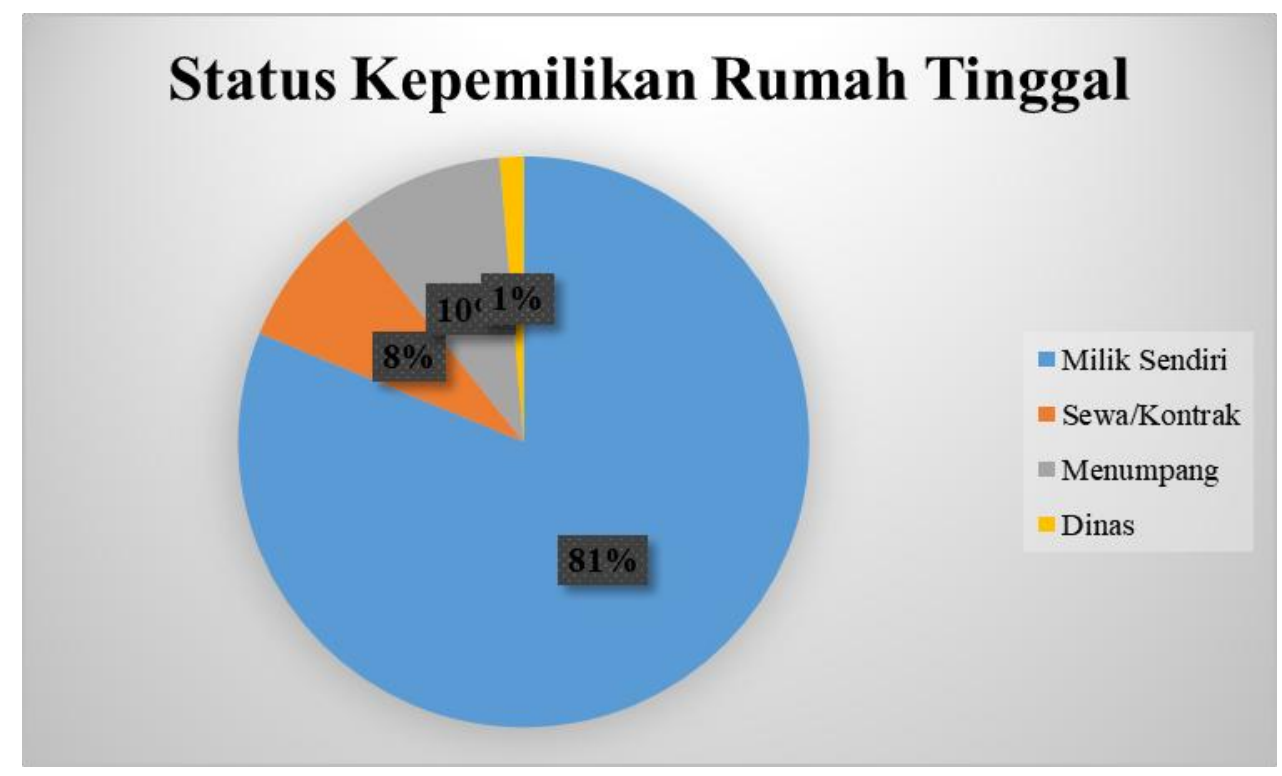

Gambar 5. Status Kepemilikan Rumah Sumber: Analisis, 2017

\section{Sistem Aliran Air Hujan}

Sistem aliran air hujan yang diterapkan oleh warga di Kelurahan Sungai Bangkong cukup bervariasi. Namun dalam Gambar 6 di bawah ini memperlihatkan, bahwa sistem talang air hujan 
yang langsung dialirkan ke penampungan air hujan merupakan sistem yang paling banyak diterapkan oleh warga (82\%). Sedangkan 6\% warga lainnya tidak menggunakan talang air dan 3\% menggunakan talang namun langsung dialirkan ke tanah, yang berarti bahwa air hujan dari atap langsung jatuh ke tanah. Beberapa warga juga menerapkan sistem talang dan dialirkan menuju drainase halaman dan saluran kota.

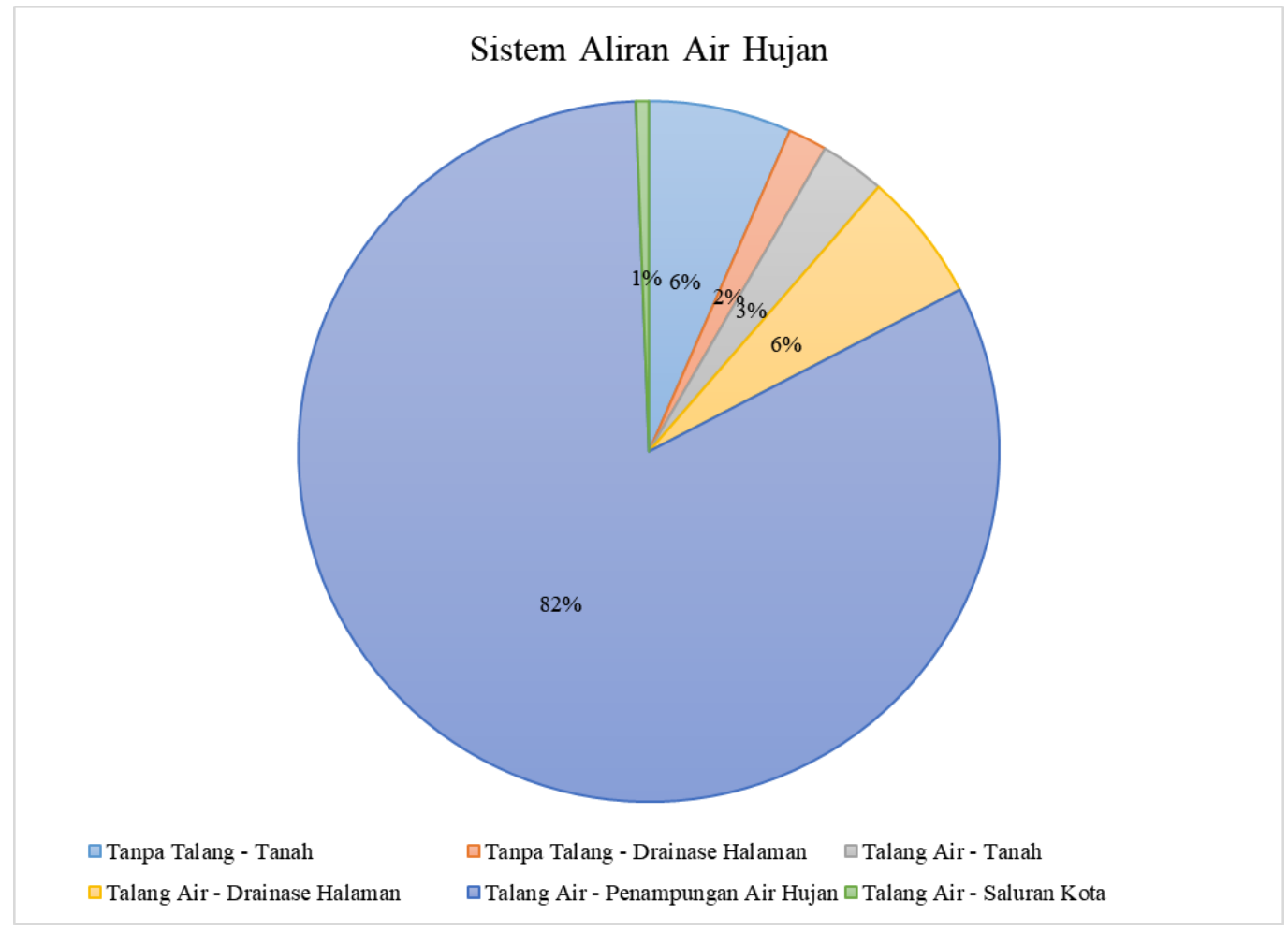

Gambar 6. Sistem Aliran Air Hujan

Sumber : Analisis, 2017

\section{Air Bersih}

\section{A. Penampungan Air}

Terdapat 6 jenis penampungan yang terdapat di Kelurahan Sungai Bangkong dengan kapasitas dan jumlah yang berbeda-beda pada tiap jenis penampungan tersebut. Jenis penampungan ferosemen (tong semen) merupakan jenis penampungan yang paling banyak digunakan di Kelurahan Sungai Bangkong, setidaknya terdapat 114 sampel yang menggunakan jenis penampungan ferosemen dari total 149 sampel yang tersebar di Kelurahan Sungai Bangkong dengan rata-rata jumlah penampungan ferosemen tiap bangunan sebanyak 4 buah. Sedangkan jenis penampungan berupa tempayan kayu adalah jenis penampungan yang paling sedikit di gunakan oleh warga, dari total 149-sampel rata-rata jumlah penampungan tempayan kayu hanya 1 buah.

Penampungan air terbanyak lainnya yang digunakan oleh warga saat ini adalah menggunakan penampungan air yang terbuat dari fiber dengan berbagai variasi ukuran. Rata-rata kapasitas yang disediakan oleh warga untuk jenis ini adalah 2 unit dengan kapasitas masing-masing 356 liter. Sementara penggunaan penampungan air yang terbuat dari beton baik yang terletak di atas tanah maupun di bawah tanah juga dijumpai di Kelurahan Sungai Bangkong dengan jumlah yang juga relatif banyak. Kapasitas rata-rata penampungan dengan jenis beton yang dimiliki oleh warga di Kelurahan Sungai Bangkong adalah 671,8 liter sampai dengan 907,38 liter. 
Tabel 2. Penampungan Air Kelurahan Sungai Bangkong

\begin{tabular}{llccccc}
\hline $\begin{array}{l}\text { Jenis } \\
\text { Penampungan }\end{array}$ & Keterangan & $\begin{array}{c}\text { Mean } \\
(\mathbf{L})\end{array}$ & $\begin{array}{c}\text { Median } \\
(\mathbf{L})\end{array}$ & $\begin{array}{c}\text { Modus } \\
(\mathbf{L})\end{array}$ & $\begin{array}{c}\text { Minimum } \\
(\mathbf{L})\end{array}$ & $\begin{array}{c}\text { Maximum } \\
(\mathbf{L})\end{array}$ \\
\hline Ferosemen & Kapasitas & 329,19 & 400 & 400 & 0 & 1000 \\
\cline { 2 - 7 } & Jumlah & 4,04 & 3 & 0 & 0 & 8000 \\
\cline { 2 - 7 } Tempayan & Total & 1595,97 & 1200 & 0 & 0 & 8000 \\
\cline { 2 - 7 } & Kapasitas & 4,36 & 0 & 0 & 0 & 400 \\
\cline { 2 - 7 } Fiber & Jumlah & 0,03 & 0 & 0 & 0 & 4 \\
\cline { 2 - 7 } & Total & 12,42 & 0 & 0 & 0 & 1600 \\
\hline Bapasitas & 356,46 & 0 & 0 & 0 & 4000 \\
Tanah & Jumlah & 0,56 & 0 & 0 & 0 & 5 \\
\cline { 2 - 7 } & Total & 658,72 & 0 & 0 & 0 & 6000 \\
\hline Beton Bawah & Kapasitas & 907,38 & 0 & 0 & 0 & 50000 \\
\cline { 2 - 7 } Tanah & Jumlah & 0,09 & 0 & 0 & 0 & 1 \\
\cline { 2 - 7 } & Total & 907,38 & 0 & 0 & 0 & 50000 \\
\hline Kapasitas & 671,81 & 0 & 0 & 0 & 24000 \\
\cline { 2 - 7 } & Jumlah & 0,07 & 0 & 0 & 0 & 1 \\
\cline { 2 - 7 } & Total & 671,81 & 0 & 0 & 0 & 24000 \\
\cline { 2 - 7 } & Kapasitas & 16,11 & 0 & 0 & 0 & 200 \\
\cline { 2 - 7 } & Jumlah & 0,2 & 0 & 0 & 0 & 6 \\
\cline { 2 - 7 } & Total & 40,27 & 0 & 0 & 0 & 1200 \\
\hline
\end{tabular}

Sumber: Analisis, 2017

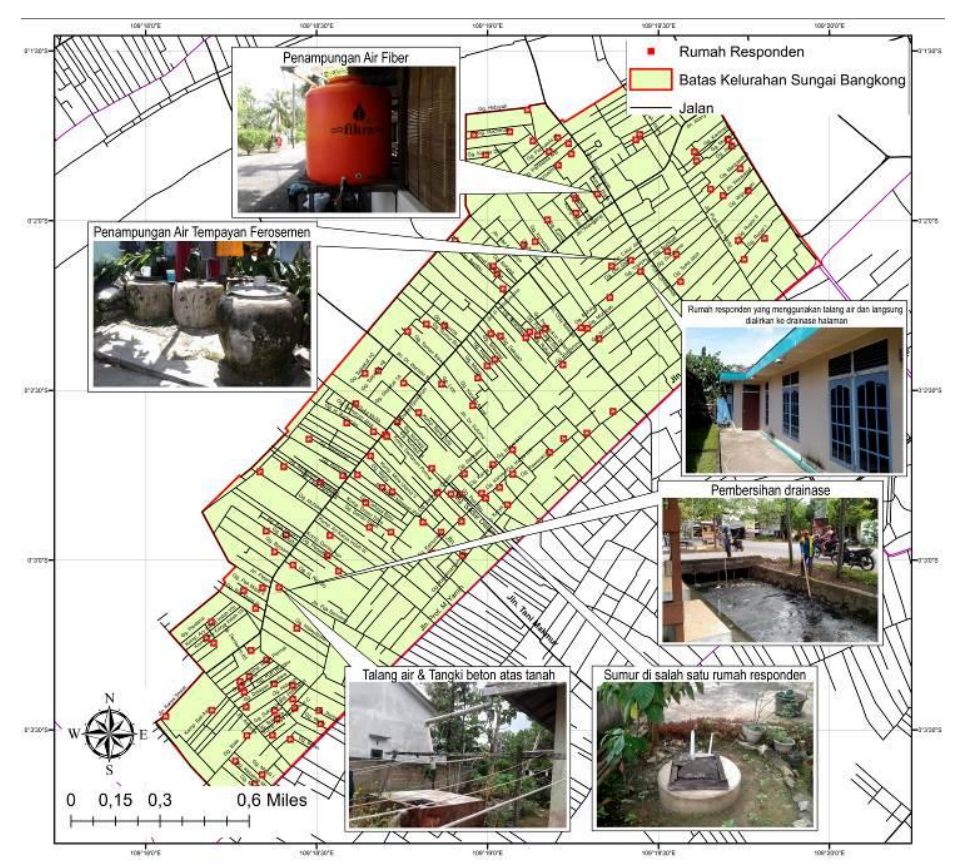

Gambar 7. Kondisi Penampungan Air Hujan di Kelurahan Sungai Bangkong Sumber: Purnomo, Kalsum, \& Caesariadi, 2017 


\section{B. Jenis Pemakaian Air Bersih}

Di Kelurahan Sungai Bangkong terdapat 5 jenis pemakaian air, yaitu untuk minum dan mengolah makanan, mandi dan membersihkan diri, mencuci pakaian dan peralatan, sanitasi dan menyiram tanaman. Berdasarkan hasil survei juga ditemukan bahwa air hujan merupakan sumber air yang paling lama digunakan warga untuk keperluan sehari-harinya, begitu pula dengan sumber air bersih yang berasal dari PDAM dan air tanah.

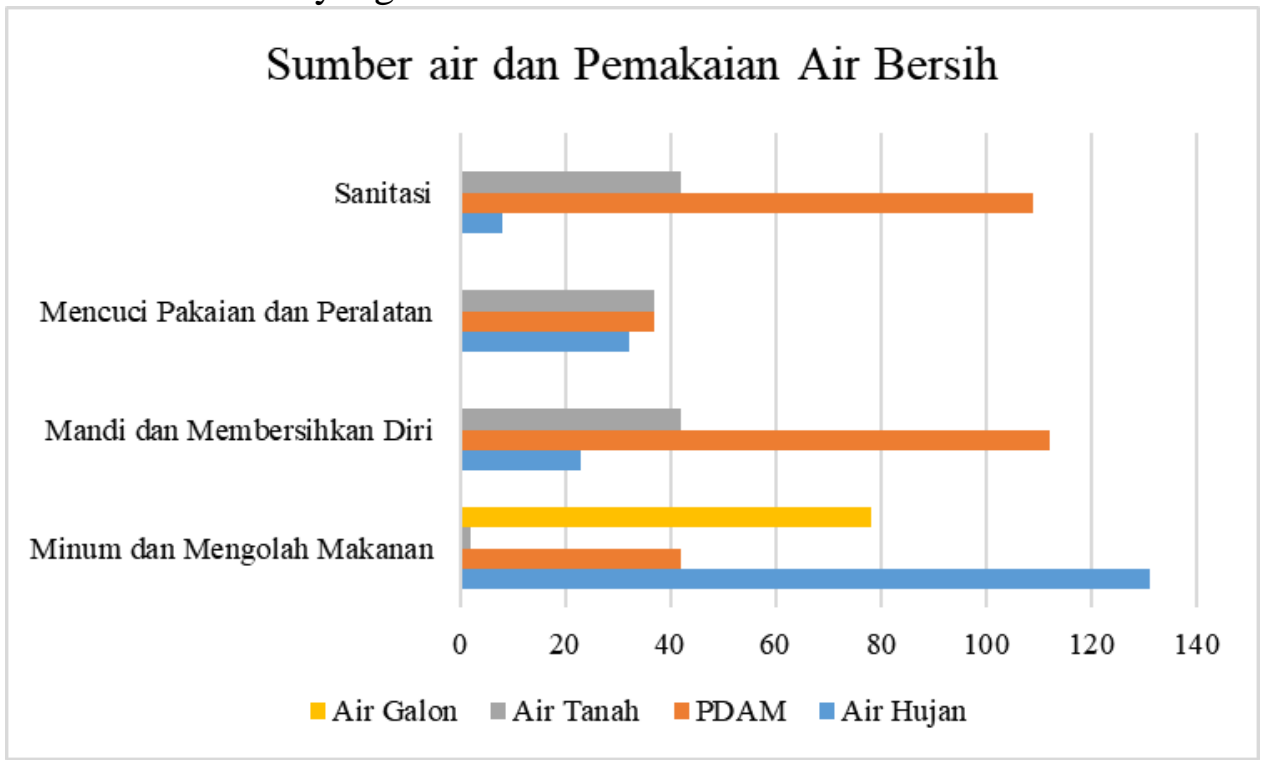

Gambar 8. Sumber air dan Jenis Pemakaian Air Bersih

Sumber: Analisis, 2017

Gambar 8 di atas memperlihatkan bahwa untuk keperluan minum dan mengolah makanan, warga di Kelurahan Sungai Bangkong lebih banyak menggunakan air bersih yang bersumber dari air hujan. Sedangkan air minum isi ulang merupakan alternatif sumber air bersih yang mulai digunakan warga dalam lima tahun terakhir ini. Air bersih yang bersumber dari PDAM paling banyak digunakan oleh warga untuk keperluan membersihkan diri dan sanitasi, sedangkan untuk mencuci pakaian dan peralatan penggunaan sumber air yang ada cukup berimbang.

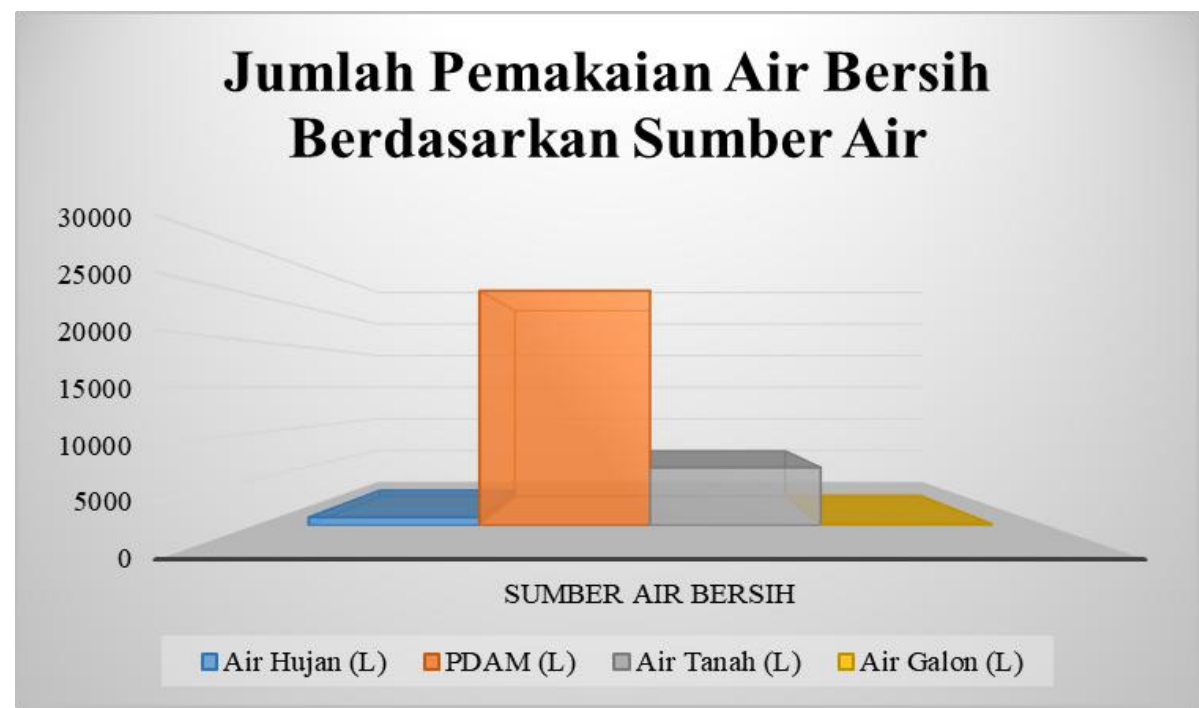

Gambar 9. Sumber air dan Jenis Pemakaian Air Bersih

Sumber: Analisis, 2017 
Gambar 9 di atas menggambarkan bahwa rata-rata pemakaian air bersih tiap bulannya di dominasi oleh penggunaan air PDAM sebanyak 25.483,34 liter di susul oleh penggunaan air tanah sebanyak 6.273,82 liter dan air hujan sebanyak 873 liter, sedangkan penggunaan air minum isi ulang hanya sebanyak 157,01 liter tiap bulannya. Gambaran ini menjelaskan bahwa walaupun sumber air bersih yang berasal dari air hujan cukup melimpah, namun warga masih enggan menggunakan air ini dengan volume yang cukup besar, sehingga sebagian besar air hujan akan menjadi air permukaan.

\section{Kesimpulan}

Berdasarkan hasil penelitian yang telah dilakukan, maka dapat diambil kesimpulan tentang gambaran pemanfaatan air hujan dan potensi genangan yang terjadi di wilayah studi kasus sebagai berikut:

1) Air hujan di wilayah Kelurahan Sungai Bangkong merupakan salah satu sumber air yang dimanfaatkan oleh warga untuk kebutuhan sehari-hari, khususnya untuk keperluan minum dan mengolah makanan.

2) Volume pemanfaatan air hujan untuk kebutuhan sehari-hari masih sangat kecil dibandingkan dengan sumber air lainnya, khususnya jika dibandingkan dengan PDAM.

3) Adanya peningkatan penggunaan sumber air yang berasal dari air minum isi ulang untuk kebutuhan minum dan mengolah makanan.

4) Sistem penampungan air hujan Curah hujan cukup banyak digunakan oleh warga, namun volume yang ditampung jauh lebih kecil dari kebutuhan air bersih yang digunakan oleh warga, sehingga lebih banyak air hujan menjadi limpasan permukaan dibandingkan yang ditampung.

\section{Daftar Pustaka}

BPS Kota Pontianak. (2017). Kota Pontianak dalam Angka 2017. Pontianak: Badan Pusat Statistik Kota Pontianak.

Lippsmeier, G. (1997). Bangunan Tropis. Jakarta: Penerbit Erlangga.

Nazir, M. (2003). Metode Penelitian. Jakarta: Penerbit Ghalia Indonesia.

Noerbambang, S. M., \& Morimura, T. (2000). Perancangan dan Pemeliharaan Sistem Plambing. Jakarta: PT. Pradnya Paramita.

Purnomo, Y., \& Wulandari, A. (2015). Infiltrasi sebagai Pendekatan Pengendalian Intensitas Pemanfaatan Ruang di Kota Pontianak. Prosiding Seminar Nasional Penerapan Ilmu Pengetahuan dan Teknologi 2015 (hal. 259-272). Pontianak: Universitas Tanjungpura.
Purnomo, Y., \& Wulandari, A. (2017). Presipitasi dalam Perencanaan Arsitektur di Kota Pontianak. Prosiding Seminar Nasional Penerapan Ilmu Pengetahuan dan Teknologi 2017. Pontianak: Universitas Tanjungpura.

Purnomo, Y., Kalsum, E., \& Caesariadi, T. W. (2017). Strategi Perencanaan Perumahan terhadap Presipitasi di Kota Pontianak. Pontianak: Tidak dipublikasikan.

Santoso, S. (2015). Menguasai Statistik Parametrik : Konsep dan Aplikasi dengan SPSS. Jakarta: PT Elex Media Komputindo.

Sujarweni, V. (2015). Statistik untuk Bisnis dan Ekonomi. Yogyakarta: Pustaka Baru Press.

Tangoro, D. (2006). Utilitas Bangunan. Jakarta: Penerbit Universitas Indonesia. 